\title{
DEFINING THE RIGHT TO STRIKE: A COMPARATIVE ANALYSIS OF INTERNATIONAL LABOUR ORGANIZATION STANDARDS AND SOUTH AFRICAN LAW
}

\author{
Mohamed Alli Chicktay \\ BProc LLB LLM PhD \\ Senior Lecturer in Law \\ University of the Witwatersrand
}

\section{SUMMARY}

The right to strike is a fundamental human right recognized in international law and the South African Constitution. If "strike" is defined too narrowly it would deny protection that would normally be given to employees who would otherwise be participating in a strike. On the other hand if "strike" were defined too broadly it would categorize as strike action that would not normally be regarded as a strike: thus subjecting these employees to serious consequences that result from participating in an unprotected strike. These may include dismissals, interdicts and claims for compensation. South Africa has a constitutional obligation to comply with international law when interpreting human rights. The purpose of this article is to determine whether South African law defines "strike" in compliance with International Labour Organisation standards and to make suggestions for amendments to the law where it fails to do so.

\section{$1 \quad$ INTRODUCTION}

The right to strike has been recognized as a fundamental right in international law and South African law. Article 4 of The Right to Organize and Collective Bargaining, Convention 98 of 1949 provides that: "Measures appropriate to national conditions shall be taken, where necessary, to encourage and promote the full development and utilization of machinery for voluntary negotiation between employers or employers' organizations and workers' organizations, with a view to the regulation of terms and conditions of employment by means of collective agreements." Even though article 4 states nothing about the right to strike the International Labour Organisation has used article 4 of The Right to Organize and Collective Bargaining Convention to lay down minimum standards relating to an employee's right to strike. ${ }^{1}$

Potobsky International Labour Law (1995) 98. 
In South Africa employees have a constitutional right to strike and to comply with international law. Section 27 of the Constitution of the Republic of South Africa, 1996, provides all workers with labour rights including the right to strike. When interpreting these rights section 39 of the 1996 Constitution obliges courts and tribunals to have regard to international law, which includes ILO standards. ${ }^{2}$ This right to strike is also given effect to in chapter IV of the South African Labour Relations Act 66 of 1995 (LRA). Section $1^{3}$ of the Labour Relations Act states specifically that the purpose of this Act "is to give effect to South Africa's obligations as a member of the International Labour Organization". In addition to this, section $3^{4}$ of the LRA, requires interpretation of the LRA in accordance with our international law obligations.

2 The only major difference between s 35 of the interim Constitution and s 39 of the 1996 Constitution is that s 35 creates an obligation on "a court of law" whereas s 39 creates an obligation on a "court, tribunal or forum". S 39 of the 1996 Constitution is therefore broader. The consideration of international law when interpreting the Bill of Rights is not only restricted to courts, as set out in the interim Constitution, but also applies to tribunals and forums which are not courts eg, the Commission for Conciliation Mediation and Arbitration (CCMA). The importance of international law is further emphasized by the fact that courts do not only have to consider international human-rights instruments that South Africa has ratified but also instruments that it has not ratified. In S v Makwanyane 1995 (3) SA 391 (CC) Chaskalson P indicated that 'In the context of $s 35(1)$, public international law would include non-binding as well as binding law. They may both be used under the section as tools of interpretation. International agreements and public international law accordingly provide a framework within which the Bill of Rights can be evaluated and understood, or for that purpose, decisions of tribunals dealing with comparable instruments, such as the United Nations Committee on Human Rights, the Inter-American Commission on Human Rights, the Inter-American Court on Human Rights, the European Commission on Human Rights, and the European Court of Human Rights and, in appropriate cases, reports of specialized agencies such as the International Labour Organization, may provide guidance as to correct the interpretation of particular provisions of the Bill of Rights.

31 Purpose of this Act

The purpose of this Act is to advance economic development, social justice, labour peace and the democratization of the workplace by fulfilling the primary objects of this Act, which are -

(a) to give effect to and regulate the fundamental rights conferred by section 27 of the Constitution;

(b) to give effect to obligations incurred by the Republic as a member state of the International Labour Organization;

(c) to provide a framework within which employees and their trade unions, employers and employers' organizations can -

(i) collectively bargain to determine wages, terms and conditions of employment and other matters of mutual interest; and

(ii) formulate industrial policy; and

(d) to promote -

(i) orderly collective bargaining;

(ii) collective bargaining at sectoral level;

(iii) employee participation in decision-making in the workplace; and

(iv) the effective resolution of labour disputes.

43 Interpretation of this Act

Any person applying this Act must interpret its provisions-

(a) to give effect to its primary objects;

(b) in compliance with the Constitution; and

(c) in compliance with the public international-law obligations of the Republic. 
The purpose of this article is to analyse the manner in which the right to strike is defined in South African law and international law and to suggest amendments to South African law where it fails to comply with ILO standards. It is important to define the right to strike correctly. If a strike is defined very broadly it may cover employee conduct in situations where they may not have intended to strike, thus subjecting them to the severe consequences of an unprotected strike, which may include dismissals or possible claims for compensation. On the other hand if a strike is defined very narrowly it may prohibit employees from partaking in industrial action, thus negating the essence of the right to strike. To be defined as a strike there are three general requirements in South African and International law. First, the action must take on a particular form. Secondly the strike must have a particular purpose and thirdly to be a strike it must be called by the legitimate authorities. Each of these three aspects of the strike definition within ILO and LRA standards will be assessed and compared.

\section{THE STRIKE DEFINITION}

\section{The purpose of the strike}

All strikes must have a purpose. ${ }^{5}$ A mere stoppage of work would not amount to a strike. ${ }^{6}$ The stoppage must be for a particular reason or demand. ${ }^{7}$ In Floraline $v$ SASTU ${ }^{8}$ and FAWU $v$ Rainbow Chicken Farms ${ }^{9}$ the Labour Court held that there was no strike, since, although there was a stoppage of work, there was no purpose or demand. This is both a requirement for the ILO and the LRA. Both recognize that strikes could exist for three different types of purposes. These include employment interests, protest action and secondary strikes.

\section{To promote employment interests}

For most employees, the primary purpose of striking relates to disputes of an occupational nature with their employer. Such a purpose is regarded by the ILO and the LRA as legitimate. According to the ILO Committee of Experts ${ }^{10}$ and the Committee on Freedom of Association, ${ }^{11}$ the right to strike could be used by workers to protect employment interests between employers and

\footnotetext{
Nel Industrial Relations (1997) 190.

The definition of strikes and protest action in section 213 of the LRA states that the strike or protest action must be "a concerted effort". The word "concerted" indicates that the strikers must have a common goal and must act together to achieve that objective.

Finnemore Introduction to Labour Relations in South Africa (1999) 224. 1997 (9) BLLR 1223 (LC).

(2000) 21 ILJ 611 (LC).

See ILO Digest of Decisions and Principles of the Freedom of Association Committee of the Governing Body of the ILO 3ed (1985) par 362, 363 and 364.

11 See Case No 1018 (Morocco) 214th Report of the CFEA; Case No 1295(United Kingdom) 238th Report of the CFEA; Case No 1068 (Greece) 214th Report of the CFEA; Case No 1131 (Upper Volta) 22nd Report of the CFEA; Case No 772 (Spain) 139th Report of the CFEA.
} 
employees. These are often referred to as primary strikes since the strikers have a material interest in the outcome of the dispute. In a case involving Canada, ${ }^{12}$ where employee unions were prohibited from striking during collective bargaining, the Committee on Freedom of Association held that the right to strike is one of the legitimate and essential means through which workers and their organizations may defend their economic and social interests at work. A similar viewpoint was expressed in a case involving Morocco, where government workers who went on strike were dismissed, imprisoned and injured by the police. The Committee on Freedom of Association held that the right to strike constitutes one of the essential means that workers and workers' organizations must have at their disposal in order to promote and defend their occupational interests. ${ }^{13}$

In South African law employees may also strike to promote employment interests in the workplace. According to section 213 of the LRA, the purpose of a strike must be to "remedy a grievance or resolve a dispute in respect of any matter of mutual interest between employer and employee". ${ }^{14}$ According to Basson, the concept "matters of mutual interest" is wide enough to include matters concerning terms and conditions of employment, matters of direct relevance to the workplace, issues relating to job security of employees, disputes about health and safety issues and issues relating to discipline, ${ }_{16}^{15}$ in fact, any matter of mutual interest provided that the demand is lawful. ${ }^{16}$ In terms of both ILO standards and South African law employees are thus allowed to strike for a wide range of occupational interest of relevance to the workplace.

\section{Protest action}

Strikes are not restricted to issues likely to be resolved through collective agreements. ${ }^{17}$ Workers do not only have the right to strike on issues relating to better working conditions or collective claims of an occupational nature, but may also strike on economic- and social-policy issues of direct concern

2 Case No 2145 (Canada) 27th Report No 327 of the CFEA.

13 The Local United Trade Unions of Casablanca v Morocco Report no 214 (Vol LXV, Series B, No 1).

14 In Rand Tyres \& Accessories $v$ Industrial Council for the Motor Industry (Transvaal) 1941 TPD 108115 the court said "whatever can be fairly and reasonably regarded as calculated to promote the well-being of the trade concerned, must be of mutual interest to them; and there can be no justification for restricting in any way powers which the Legislature has been at the greatest pains to frame in the widest possible language". It does not matter whether strikers refer to the issue as a grievance, dispute or demand the courts will look at substance over form. See SATAWU v Coin Reactions (2005) 26 ILJ 1507 (LC); and see also City of Johannesburg Metropolitan Municipality v SAMWU (2011) 7 BLLR 63 (LC).

15 The purpose is much broader than the 1956 LRA, which only allowed industrial action whose purpose is to induce or compel an employer to comply with a demand. See Basson Essential Labour Law (2009) 107. The term is broad enough to cover primary strikes and sympathy strikes. With primary strikes employees have a material interest in the outcome of the dispute. With sympathy strikes employees are striking on behalf of their colleagues demands and do not benefit from the outcome of the dispute.

16 City of Johannesburg Metropolitan Municipality v SAMWU (2009) 5 BLLR 431 (LC).

17 Case No 913 (Sri Lanka) $190^{\text {th }}$ Report of the CFEA. 
to workers. ${ }^{18}$ This includes strikes aimed at challenging a government's economic and social policy. ${ }^{19}$ This was expressed clearly by the ILO Committee on Freedom of Association and is specifically protected by the LRA. In a case, ${ }^{20}$ where the Peruvian government prohibited protest action, ${ }^{21}$ the Committee on Freedom of Association held that strikes are one of the essential means available to workers and their organizations for the promotion and protection of their occupational and economic interests in the broad sense of the term. It said further that these interests do not only have to do with obtaining better working conditions but also with seeking solutions to economic- and social-policy questions and to labour problems of any kind, which are of direct concern to the workers. The ILO has applied this principle to enable employees to protest against a wide range of socio-economic issues adopted by the government. For example, in Ecuador a 24-hour general strike forcing the government to change its economic policy by reducing prices and unemployment was declared permissible by the Committee on Freedom of Association. ${ }^{22}$ In a case involving Colombia ${ }^{23}$ the Committee held that a protest strike demanding that an end be put to the killings of trade-union members was permissible and in accordance with the principles of freedom of association. ${ }^{24}$

The South African law on protest action complies with ILO standards. However, this was not always the case. Prior to the 1994 elections protest action, in the form of stay-aways, against the South African apartheid regime was a common occurrence. The 1956 Labour Relations Act prohibited such action and employees that participated in it were often dismissed. ${ }^{25}$ In 1992 the International Labour Organization's Fact Finding and Conciliation Committee investigated aspects of the 1956 LRA and requested that workers be given the right to strike in order to promote and defend their socio-economic interests.

A prohibition of protest action in South Africa was also unconstitutional since it violated a number of constitutional rights, including the right to strike, the right to freedom of expression and the right to assemble and demonstrate with others in a peaceful manner.

18 ILO Digest of Decisions and Principles of the Freedom of Association Committee of the Governing Body of the ILO par 368.

19 ILO: Committee of Experts on the Application of Conventions and Recommendations Freedom of Association and Collective Bargaining Report III (1983) 67.

20 Case No 1081 (Peru) 214th Report of the CFEA.

21 S 4. Strikes by workers shall be intended for: (a) obtaining better economic and working conditions; and (b) ensuring compliance by the employer of provisions of law or collective agreements and the restoration of any of the workers' rights and benefits that may have been infringed or prejudiced.

22 Case No 1381 (Equador) 248th Report of the CFEA.

23 Case No 1434 (Colombia) 265th Report of the CFEA.

24 Case No 1081 (Columbia) 214th Report of the CFEA; Case No 722 (Spain) 139th Report of the CFEA; Case No 756 (India) 147th Report of the CFEA; Case No 709 (Mauritius) 149th Report of the CFEA; Case No 1025 (Haiti) 211th Report of the CFEA.

25 Basson Essential Labour Law (2002) 160.

26 "Explanatory Memorandum of the LRA" proposed by the Ministerial Legal Task Team in January 1995 to be found in (1995) 16 ILJ 278307 . See also a summary of the ILO findings to be found in (1992) 8 Employment Law 121121. 
In order to give effect to its international and constitutional obligations, the South African Parliament passed the 1995 LRA and gave specific protection to protest action in sections 213 and 77 of the LRA. ${ }^{27}$ Section 213 of the LRA defines protest action as "[t]he partial or complete concerted refusal to work, or the retardation or obstruction of work, for the purpose of promoting or defending the socio-economic interest of workers, but not for the purpose referred to in the definition of a strike".

Protest action may take the same form as a normal strike. However, in terms of the definition, the purpose of a protest action differs from that of a strike. Whereas the object of a normal primary strike is to force an employer to accept a demand on any matter of mutual interest between the parties, the object of a protest action is to promote the socio-economic interests of workers.

The term "socio-economic interest" is not defined in the $\mathrm{Act}^{28}$ but was dealt with by the Labour Court in the Government of the Western Cape Province $v$ Congress of COSATU. ${ }^{29}$ In this case COSATU intended to partake in a protest action to demonstrate against the province's education crisis. $^{30}$ One of the issues before the court was whether protests against the poor state of education fell within the meaning of "socio-economic interest" in the definition of protest action. The court held that it is not possible to provide an all-embracing definition of "socio-economic interest" and that each matter should be viewed on its own merits. It held further that workers have an interest in ensuring that their children do not suffer the same ills that befell them as a result of the distorted policies of the past and that COSATU's demands to redress the disparities and imbalances in education were nothing more than a legitimate criticism of the Western Cape education policy. It thus found that the protest action was protected since it was

27 Cooper "Strikes and Lock-outs in the New LRA" 199620 SALB 80 85.According to Cooper the LRA balances an employee's right to strike with the need of the economy by providing constraints on the exercise of such action as found in s 77 and 213 of the LRA. Lagrange "Labour Law" 1995 Annual Survey of South African Law 524.

(1999) 20 ILJ 151 (LC).

COSATU made the following demands of the Western Cape provincial government:

(a) the provincial government must accept the financial aid from the National government and use this to finance and remedy the education crisis in the province;

(b) the provincial government must reprioritize its budget to ensure that it reflects the prioritization of education in black working-class areas:

(c) the provincial government must not withdraw any support measure given to disadvantaged communities, eg, buses

(d) the provincial government must continue to fund municipal costs of schooling;

(e) a guarantee of equality in public education and the removal of overcrowding;

(f) the provincial government must take measures to remove the imbalances created by apartheid between black and white schools;

(g) the provincial government must bargain in good faith with labour;

(h) the provincial government must not pass any additional costs on schools and parents;

(i) the provincial government must adopt a funding mechanism that will address the disparities between previously advantaged and disadvantaged schools;

(j) the provincial government must redress imbalances, inequities and the development needs of the people of the Western Cape. 
designed to serve the socio-economic interests of its members and of workers in general. ${ }^{31}$

To sum up, both the ILO and the LRA allow workers to strike against their government's social and economic policies. Both have adopted a broad definition of the term "socio-economic", requiring each case to be dealt with on its own merits.

In addition, both instruments do not protect purely political strikes. ${ }^{32}$ The ILO supervisory bodies have held that strikes of a purely political character do not fall within the ambit of the principle of freedom of association. ${ }^{33}$ Any protest action in South Africa would also only be lawful if it has a socioeconomic purpose, hence strikes that are merely political would not be acceptable.

\section{Secondary strikes}

Employees working for an employer who is not party to a primary strike may engage in a secondary strike against this employer in order to show their support for the primary strike. ${ }^{34}$ In such cases employees do not have a personal interest in the outcome of the dispute. ${ }^{35}$ The purpose of their strike is merely to assist other employees on strike against another employer. ${ }^{36}$ In order that an effective primary strike may occur, there must be some link between the primary and secondary employers. Secondary strikes are recognized by both the ILO and the LRA.

The ILO Committee on Freedom of Association has indicated that such strikes are lawful. When Turkey ${ }^{37}$ banned secondary strikes, ${ }^{38}$ the

31 Government of the Western Cape Province v Congress of COSATU (1999) 20 ILJ 151 (LC) 152. For an analysis of the case see Grogan "Case Roundup" 199914 Employment Law 21

32 For more on political strikes see Nadesan "Strike for the Purpose of Collective Bargaining The Place of the Political Strike in a Democracy" 1997 TSAR 117.

33 Case No 1830 (Turkey) 303rd Report of the CFEA. This is similar to the principle adopted by the European Social Charter Experts, who have held that article 6 of the European Social Charter does not protect political strikes. See ESC Committee of Experts Conclusion 2 (1971) 27.

34 Brassey Commentary on the Labour Relations Act Vol 3 (1999) A4: 32.

35 Secondary strikes differ from sympathy strikes. With a sympathy strike employees strike against their own employer in order to benefit their colleagues. With a secondary strike employees strike against their employer in order to benefit other employees who do not work for their employer. The distinction is crucial since different procedures and rules apply to both. The same rules that apply to primary strikes apply to sympathy strikes, while secondary strikes have different requirements. See Roskam "Strikes: Primary, Secondary or Sympathy 200226 SALB 47. See also Afrox Ltd v SACWU (1) (1997) 18 ILJ 399 (LC). Thus, where the thesis deals with primary strikes this also covers sympathy strikes.

36 Note that a secondary strike must support a primary strike against another employer. Strikes by employees in another branch from those who are on strike are not partaking in a secondary strike, but a primary strike since they are striking against the same employer. See Afrox Ltd v SACWU (2) 1997(9) BLLR 375 (LC). See an analysis of this judgment in Grogan "First Judgments" 199713 Employment Law 9598.

37 The complaint was made by the Confederation of Turkish Trade Unions (TURK-IS). It also examined jointly with this representation a complaint presented by the Confederation of Progressive Trade Unions of Turkey (DISK). 
Committee stated that this was a violation of the Freedom of Association and Protection of the Right to Organize Convention Act. ${ }^{39}$ The Committee held that the general banning of secondary strikes is abusive, and that workers should be able to carry out such actions.

In South Africa secondary strikes are regulated by section 66 of the LRA. ${ }^{40}$ Section 66(1) defines a secondary strike as "a strike or conduct in contemplation or furtherance of a strike that is in support of a strike by other employees against their employer but does not include a strike in pursuit of a demand that has been referred to a council if the striking employees employed within the registered scope of the council have a material interest in the demand". ${ }^{41}$

In terms of this definition employees can go on a secondary strike in support of a primary strike. ${ }^{42}$ The proviso to the definition, which excludes demands referred to the council by striking employees who have an interest in the demand within bargaining councils, is important. Employers and trade unions bargain collectively as an industry. When employees in a bargaining council go on strike one often finds different employees going on strike against different employers as a result of demands made at a bargaining council. Their strike may be seen to be supporting strikes against other employers within the bargaining council when in fact the employees who are on strike are actually undertaking industrial action against their own employer for compliance with demands referred to the council in which they have an interest. These employees are actually engaging in a primary strike and are correctly excluded from the definition of a secondary strike. ${ }^{43}$

Both the ILO and the LRA thus protect secondary strikes. The exception in the definition of secondary strikes in the LRA merely makes it clear that strikes in bargaining councils and statutory councils are primary strikes and

38 Case No 1830 (Turkey) 303rd Report of the CFEA.

3987 of 1948.

40 During the drafting of the LRA Business South Africa was opposed to the inclusion of secondary strikes in the Act so the inclusion was a victory for labour. See Provisions of the Labour Relations Act: Part 319951 Labour-Business Monitor 10.

41 S 66(1) of the LRA. According to the ministerial task team the primary purpose for protecting secondary strikes is to ensure that the LRA complies with ILO standards. See the Ministerial Task Team "Explanatory Memorandum" (1995) 16 ILJ 278306.

42 Finnemore Introduction to Labour Relations in South Africa 227; and Olivier "A New Labour Relations Act" June 1995 De Rebus 357360.

43 Also excluded from s 66 application are sympathy strikes. Unlike secondary strikes, which support workers employed by another employer, in a sympathy strike employees go on strike against their employer in support of their colleagues demands. In terms of the LRA such strikes are not secondary strikes and must follow the same procedure that regulate primary strikes. ie a s 64 procedure. In Afrox Ltd v SACWU (1) (1997) 18 ILJ 399 (LAC) the Labour Appeal Court held that employees who went on strike in support of their colleagues were not partaking in a secondary strike since there was only one employer involved. It found that in order for these employees to partake in a protected strike it had to comply with a s 64 procedure and not a s 66 procedure which is only applicable to secondary strikes. A similar viewpoint was adopted in CWIU v Plascon Decorative Inland (Pty) Ltd (1999) 20 ILJ 321 (LAC). Thus, according to these judgments employees do not have to benefit from the outcome of the strike when assisting colleagues who have an interest in the dispute. For more on the distinction between primary, secondary and sympathy strikes see Roskam 200226 SALB 47. 
not secondary strikes. The definition of secondary strikes in South African law thus complies with ILO standards.

\section{The form that the strike should take}

Industrial action may take various forms including complete strikes, goslows, ${ }^{44}$ work-to-rule, grasshopper strikes and sit-ins. In the case of a complete strike, employees cease doing all the work that is required of them. In a grasshopper strike employees call a strike, temporarily suspend it, and later resume it. ${ }^{45}$ In work-to-rule strike employees do their work strictly in accordance with their contracts and do no more than the minimum. In a goslow employees do their work at a reduced pace. In the case of sit-ins employees refuse to do their work and occupy the premises of the employer. According to the ILO Committee of Experts all such strike action is acceptable provided that it is peaceful. ${ }^{46}$ In a case involving Turkey, ${ }^{47}$ the ILO Committee on Freedom of Association held that section 25 of Act 2822 violated ILO principles since it prohibited solidarity strikes, general strikes, work stoppages and go-slows. The Committee on Freedom of Association indicated that a general prohibition of sympathy strikes could lead to abuses and section 25 restrictions on working to rule; occupations of work premises and sit-down strikes can only be justified if the action ceases to be peaceful. A similar viewpoint was expressed in a case against the Government of Peru. ${ }^{48}$ Section 81 of the Peruvian Legislative Decree ${ }^{49}$ prohibited go-slow strikes and work-to-rule strikes. The Committee on Freedom of Association held that section 81 is justifiable only if the strike ceases to be peaceful..$^{50}$

According to the ILO, strike action may thus take various forms provided that they are peaceful. Similar provisions apply to South Africa. Section 213 of the Labour Relations Act states that a strike or protest action may take the form of a partial or complete refusal to work or a retardation or obstruction of work. It may also take the form of a refusal to do any overtime work. ${ }^{51}$ These forms will be discussed in greater detail below.

44 Van Heerden "Protected Strikes - Getting the Balance Right" 2011 Without Prejudice 66.

45 This was a type of strike dealt with in AECI Chlor-Alkali \& Plastics Ltd and Others v SACWU (1986) 7 ILJ 300 (LC).

46 ILC 69th Session, Report III, Freedom of Association and Collective Bargaining. General Survey (1983) 76.

47 Case No 997 (Turkey) 260th Report of the CFEA.

48 Case No 1648 (Peru) 291st Report of the CFEA.

49 Decree No. 25593, known as the Industrial Relations Act of 1992.

50 For similar views see Case No 997 (Turkey) 260th Report of the CFEA.

51 Refusal to do overtime work is not stated as a form of protest action in the definition of "protest action" found in s 213 of the LRA. It is thus arguable that such forms of action would not be regarded as a legitimate protest action. 


\section{Complete refusal to work}

A complete refusal to work occurs in cases where the employee refuses to do any work at all. ${ }^{52}$

\section{Partial refusal to work}

In a partial strike the employees do not desist from work completely, but only cease doing part of their work. ${ }^{53}$ Partial strikes are usually early warning signals by employees to show the employer that they feel strongly about an issue which, if not addressed, may result in a complete strike. ${ }^{54}$ Examples of partial strikes include grasshopper/intermittent strikes, overtime bans and work-to-rule strikes.

\section{Retardation of work}

Retardation of work occurs in cases where employees do their work at a lower level of productivity. ${ }^{55}$ Examples of such strikes include go-slows.

\section{Obstruction of work}

Strikes that take the form of the obstruction of work involve employees preventing work from being done. ${ }^{56} \mathrm{~A}$ sit-down strike constitutes an example of this form of strike. ${ }^{57}$ In a sit-down strike workers do not leave the premises, but remain there in an attempt to prevent others from doing their work. ${ }^{58}$

\section{Refusal to do overtime work (also known as an overtime ban)}

The refusal to do overtime work is stated in the definition of strikes but not in the definition of protest action. In the case of overtime bans an employee refuses to do overtime work. ${ }^{59}$ Overtime bans are used in South Africa for a

52 To be on strike the employee must refuse to do work that he is legally required to do. A refusal to do illegal work is not a strike. In Simba (Pty) Ltd v FAWU 1997 (5) BLLR 614 (LC) the Labour Court held that the employees' refusal to work hours in violation of the Basic Conditions of Employment Act was not a strike. See an analysis of this judgment in Grogan 199713 Employment Law 102.

53 An example of a partial strike includes a grasshopper/intermittent strike. In a grasshopper strike employees call for a strike, temporarily suspend it, and later resume the strike. This was a type of strike dealt with in AECI Chlor-Alkali \& Plastics Ltd v SACWU (1986) 7 ILJ $300(\mathrm{~W})$. Other types of partial strikes include overtime bans and work-to-rule, which will be dealt with in more detail below.

54 Albertyn "Strike rules II" 199411 Employment Law 11.

55 Du Toit Labour Relations Law (2006) 293.

56 Landman "The Right to Strike and the Right to Lockout in a New Labour Dispensation" 1995 3 Contemporary Labour Law 8587.

57 Grogan Workplace Law 10ed (2010) 368.

58 Nel South African Industrial Relations Theory and Practice 3ed (1997) 189.

59 Olivier June 1995 De Rebus 360. 
variety of reasons. First, these are used as pressure tactics to obtain various demands of mutual interest between the parties. Second, they are often used by COSATU for job creation. ${ }^{60}$ If employees refuse to do overtime work then the employer is forced to employ others to do this work. Prior to the adoption of the 1995 LRA the case law was inconsistent on whether voluntary overtime could be regarded as work. Some decisions ${ }^{61}$ held that voluntary overtime does not constitute work and therefore the refusal by employees to do voluntary overtime does not amount to a strike. On the other hand, other decisions ${ }^{62}$ held that work included voluntary overtime work and thus a refusal to do such work would amount to a strike. This inconsistency in the law was finally settled when the LRA was adopted. The definition of a strike in section 213 of the LRA specifically regards voluntary ${ }^{63}$ and compulsory overtime as work. ${ }^{64}$ However, this provision was not included in the definition of protest action and thus only applies to primary and secondary strikes. A refusal to do either would amount to a strike. In terms of the Basic Conditions of Employment $\mathrm{Act}^{65}$ an employer may not permit an employee to work more than three hours overtime a day or ten hours overtime a week. The BCEA overrides contractual provisions contrary to the Act. ${ }^{66} \mathrm{~A}$ ban on illegal overtime beyond the limits of the BCEA could therefore not be regarded as a strike ${ }^{67} \mathrm{~A}$ refusal to do overtime work would only be accepted as a primary or as a secondary strike but not as a protest action. It is unclear why the drafters of the legislation excluded overtime bans from the definition of protest action. ${ }^{68}$ It is likely that employees could be protesting when requested to conduct overtime work. Their refusal to do this work would not amount to a protected protest action neither would it amount to a protected strike subjecting protesters to severe consequences

Finnemore Introduction to Labour Relations in South Africa 226.

1 Tiger Bakeries Ltd v Food and Allied Workers Union (1988) 9 ILJ 82 (W); and R v Canqan 1956 (3) SA 366 (E). In FAWU v SAB (1989) 10 ILJ 844 (A) the Appellate Division, as it then was, held that voluntary overtime was not embraced in the concept of work. In $S A$ Breweries LTD v FAWU 1990 (1) SA 92 (A) the Appellate Division, as it then was, held that the word "work" in the definition of a strike in s 1 of the LRA 28 of 1956 "must be limited to mean work that an employee is contractually obliged to perform' and thus 'a refusal to do voluntary overtime work, does not amount to a strike".

62 Plascon Evans Paint (Natal) Ltd v Chemical Workers Industrial Union (1998) 10 ILJ 239 (C); and Bebel Investments (Pty.) Ltd t/a East London Furniture Industries v PPWAWU (1998) 9 ILJ 572 (E).

63 Ford Motor Co of South Africa v NUM (2008) 29 ILJ 667 (LC).

64 Cooper 199620 SALB 81.

6575 of 1997.

66 In Simba (Pty) Ltd v FAWU 1997 (5) BLLR 602 (LC) the employer asked employees to work for longer than the required hours specified in the 1983 BCEA. Employees refused to work these extra hours. When the employer applied to the Labour Court to interdict employees from striking, the Labour Court refused to grant it to them. It held that the employees' refusal to do unlawful work beyond the limits specified in the BCEA does not amount to a strike. Zondo AJ said specifically that "the word 'work' in the strike definition did not include work the performance of which would be illegal" (603 par C).

67 Lagrange 1995 Annual Survey of South African Law 518.

68 One would think that this is so, because the drafters of the LRA wanted to prevent innocent employers from being unduly prejudiced by being denied the use of overtime work when needed. This argument does not carry much weight since other forms of protest action would cause just as much harm to the innocent employer as a refusal to do overtime work. 
applicable to unprotected strikes and protest action. It is thus submitted that in order to provide protesters with meaningful protection the definition of protest action be amended to include a refusal to do overtime work.

\section{Violent strike action ${ }^{69}$}

Although strikes that are a threat to peace are not expressly prohibited by the definition of strikes and protest action as described in section 213 of the LRA, they are prohibited implicitly elsewhere in the LRA. According to section $67(8)$ of the LRA strikers may be deictically and contractually liable for offences committed during a strike. They may also be interdicted from continuing the strike. ${ }^{70}$ Strikers who disrupt the peace may be dismissed for misconduct if this is justified, ${ }^{71}$ and they may also be criminally charged. ${ }^{72}$

\section{Comparing South African law and ILO standards on the form that a strike can take}

South African law thus recognizes a wide range of conduct as strikes. However, unlike complete strikes, other strikes, such as partial strikes, grasshopper/intermittent strikes, work-to-rule strikes, go-slows, obstruction of work and overtime bans, can be more disruptive and difficult to manage. ${ }^{73}$ For instance, employers continue to pay employees who engage in partial strikes; thus spending public funds for services that are not adequately provided. In the case of obstruction-of-work strikes, striking employees not only refrain from doing their work, but also prevent other employees who are not on strike from working. With go-slows and grasshopper strikes, employees do their work at a reduced pace, confusing students, particularly younger student. Because of these difficulties such strikes are prohibited in some countries, such as France and Italy, ${ }^{74}$ which only allow employees to partake in complete strikes. Despite these potential problems, all these forms of strikes are recognized as valid by the ILO and the LRA, irrespective of whether the strike is a primary or secondary strike, or a protest action. ${ }^{75}$ All employers, viz primary employers, secondary employers as well as employers who are the object of protest action, are thus subjected to all forms of strikes, which may be overly disruptive and difficult to manage.

It may easily be argued that secondary strikes and protest action, except in the case of complete strikes, should be prohibited because they affect employers who are not party to the dispute, and it would thus be unreasonable to subject them to strikes that are overly disruptive. However as has been intimated by the ILO restricting the form of a strike may lead to abuse. The dangers consequent upon such strikes could, however, be

69 For a discussion on violence and strikes see Levy Dispute Resolution Digest (2012) 17.

$70 \mathrm{~S} 67(8)$ of the LRA.

$71 S 67(5)$ and $77(4)$ of the LRA.

72 Nel Industrial Relations 194.

73 Bendix Industrial Relations (2010) 663.

74 Albertyn 199411 Employment Law 12.

75 With the exception of overtime bans. 
alleviated by providing employers of secondary strikers and protesters with a right to a defensive lockout. In terms of the LRA, as currently formulated, only employers in primary strikes have recourse to lockouts. According to section 213 of the LRA the purpose of a lockout must be to compel "employees to accept a demand in respect of any matter of mutual interest between employer and employee". ${ }^{76}$ This does not apply to secondary strikes since, in such cases, the dispute does not relate to a matter of mutual interest between the secondary employer and the secondary employees, but applies to a primary strike. ${ }^{77}$ The definition of lockout also does not apply to protest action, the purpose of which is to "promote or defend the socioeconomic interests of workers" interest between employer and employee.

Thus, only primary employers can escape any potential disruption that may be caused by partial strikes, grasshopper/intermittent strikes, work-torule strikes, go-slows, obstruction of work and overtime bans. ${ }^{79}$ There does not seem to be any sound reason to deny this right to employers subjected to secondary strikes and protest action. I therefore submit that the LRA be amended to allow employers of secondary strikers and protesters a recourse to defensive lockouts and to include overtime bans in the definition of protest action.

The form of strikes and protest action recognized in South African law is thus consonant with international law. Both recognize a variety of strike methods ranging from complete strikes, partial strikes, go-slows, grasshopper strikes, work-to-rule strikes, obstructions and refusal to do overtime work. Both ILO standards and the LRA also prohibit strikes that threaten the peace. There is thus no need to amend South African law as regards the form taken by strikes, except for the inclusion of overtime bans in the definition of protest action and the amendment of the definition of lockout to render the latter applicable, albeit only as a defensive mechanism to secondary strikes and protest action.

\section{Who is allowed to strike?}

In order to avoid unprotected strikes it is important to know who has the authority to call a strike. ${ }^{80}$ May individuals strike or is the right to strike restricted to groups? As regards groups, the further question arises whether the right to call a strike is open to all employees or whether it is merely a trade-union prerogative. For the ILO any of the three options are acceptable.

76 S 213 of the LRA.

77 According to $s$ 66(1) of the LRA "[s]econdary strike means a strike or conduct in contemplation or furtherance of a strike that is in support of a strike by other employees against their employer".

$78 \mathrm{~S} 213$ of the LRA.

79 They can lock them out and thus force them to undertake a complete strike. Without any agreement between employers and employees in secondary strikes and protest action or any sound reason to prohibit such action (eg, where strikers or protesters get militant), employers of secondary strikers and protesters have no such recourse.

80 Olivier June 1995 De Rebus 360. 
The individual right to strike is expressly protected by the Abolition of Forced Labour Convention. ${ }^{81}$ Article 1 of the Convention ${ }^{82}$ prohibits forced or compulsory labour being imposed on individuals as punishment for having participated in strikes. It specifically refers to the individual right to strike and does not restrict the right to a group right.

As far as groups are concerned, the ILO has held that the right to strike is available to both workers and trade unions. The Committee of Experts has held that "the right to strike is one of the essential means available to workers and their organizations". ${ }^{83}$ Although the ILO recognizes the rights of both workers and unions to call a strike, it has stated that it is acceptable for member states to adopt laws that provide unions alone with the right to call a strike. In a case concerning Greece, the ILO Committee on Freedom of Association held that legislation authorizing trade unions alone to call for strikes was legitimate. ${ }^{84}$ In such a situation workers, and especially their leaders, should be protected against any discrimination that might occur because of a strike, and they should be able to form trade unions without being exposed to anti-union discrimination. ${ }^{85}$

The ILO has held that the right given to trade unions and workers also extends to federations and confederations. In a case involving Columbia where federations were prohibited from striking, the Committee on Freedom of Association held that the prohibition is incompatible with articles 6 and 3 of Convention 87.

Thus, according to ILO standards states may adopt laws that accord the right to strike to individual workers, non-unionized and unionized workers, federations and confederations. A state may also adopt laws that provide trade unions alone with the right to call a strike, provided that this right is not denied to federations and confederations.

In South Africa, the entitlement to strike depends on whether the strike is a primary strike, secondary strike or protest action.

\section{Primary and secondary strikes}

The definition of "strikes" in section 213 of the LRA applies to both primary and secondary strikes. ${ }^{87}$ The section indicates that strikes may be called

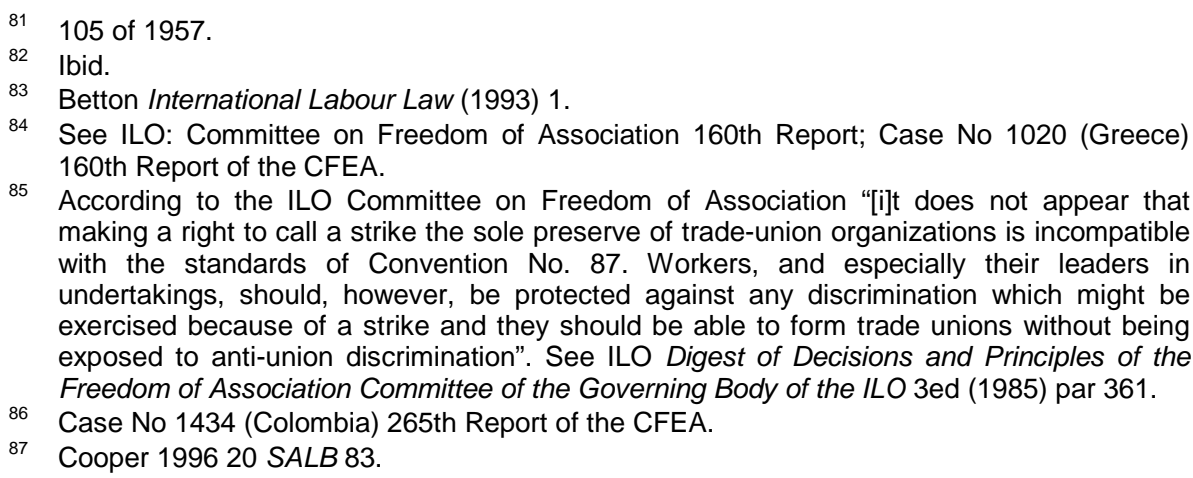

85 According to the ILO Committee on Freedom of Association "[i]t does not appear that making a right to call a strike the sole preserve of trade-union organizations is incompatible with the standards of Convention No. 87. Workers, and especially their leaders in undertakings, should, however, be protected against any discrimination which might be exercised because of a strike and they should be able to form trade unions without being exposed to anti-union discrimination". See ILO Digest of Decisions and Principles of the Freedom of Association Committee of the Governing Body of the ILO 3ed (1985) par 361. 
only "by persons who are or have been employed". Two points may be made concerning this section. First, by using the word "persons" the definition specifically excludes a single employee from going on strike. ${ }^{88}$ It requires that employees strike as a group. ${ }^{89}$ Although the LRA provides only groups of workers with the right to strike, it does not restrict this right to trade unions. ${ }^{90}$ Nowhere in Article IV of the LRA or in the definition of strikes in section 213 of the LRA is the right to strike restricted to trade unions. Thus section 213 provides unionized and non-unionized workers as well as federations and confederations with the right to strike.

Second, in addition to allowing employees to go on strike, the LRA also allows former employees to strike. ${ }^{91}$ The case law is inconsistent concerning the question which categories of former employees may strike. In Picardi Hotels Ltd v Food \& General Workers Union ${ }^{92}$ the Labour Court adopted a very broad test. Zondo $\mathrm{J}$ held that the definition in section 213 of the LRA indicates beyond any doubt that persons who have been employed by the employer are included as one of the categories of persons who may engage in a strike and therefore the mere fact that workers are dismissed does not preclude them from striking. ${ }^{93}$

In Food and General Workers Union v Minister of Safety and Security, ${ }^{94}$ on the other hand, Grogan AJ adopted a narrower test. He held that a strike continues after employees are dismissed only if the following three requirements are satisfied. First, the strike must be a protected strike.$^{95}$ Second, the strikers must have be dismissed in contravention of section 67(4) of the LRA. Section 67(4) prohibits an employer from dismissing employees for participating in a protected strike or any conduct in contemplation or furtherance of a strike. ${ }^{96}$ Protected strikers may only be dismissed for misconduct committed during the strike or for operational reasons. Where a striker is dismissed for the strike itself, this constitutes a violation of section 67(4). Third, the conduct in which the employees are engaged after their dismissal must amount to a continuation of the original strike.

There is a stark difference between the two cases. Zondo J's approach is more flexible in that it seems to allow any former employee to strike against former employers. This test is too broad and may be dangerous in that it

88 Olivier "The New Labour Relations Act-An Update" June 1995 De Rebus 767 768; and see also Schoeman v Samsung Electronics (Pty) Ltd (1997) 10 BLLR 1364 (LC).

89 Thompson and Benjamin, however, believe that it is possible for a single employee to strike in certain circumstances. See Thompson and Benjamin South African Labour Law (1995) 307. This is inconsistent with the definition, which refers to "persons" and a "concerted effort".

Landman 19953 Contemporary Labour Law 87.

For a history on this rule see Van Niekerk Law @ Work (2012) 401.

(1999) 20 ILJ 1915 (LC).

93 Hotels Ltd v Food \& General Workers Union (1999) 20 ILJ 1915 (LC) 1915 par F-G.

94 (1999) 20 ILJ 1258 (LC).

95 If it is not a protected strike, then according to Grogan the dismissal of the unprotected strikers would automatically terminate their strike unless their employment relationship is subsequently revived by the Labour Court in terms of $s$ 191(5)(b)(iii) of the LRA. Grogan Workplace Law 6ed (2001).

$96 \mathrm{~S} 67(5)$ of the LRA. 
gives former employees an unrestricted right - one that is not subject to limitations in point of time or to circumstances in which the dismissal is fair. On the other hand, Grogan AJ's test is extremely narrow, but useful. The first requirement that the strike be a protected strike makes sense in that one should discourage employees from participating in an unprotected strike. The second requirement is also acceptable. If there is a sound reason for dismissing strikers then there should be no need for them to strike. However, it is submitted that the third requirement is problematic. For Grogan AJ the strike must be a continuation of an original strike that began prior to the dismissals. Why should former employees be prohibited from beginning a strike after dismissals? Grogan AJ's third requirement may amount to an unjustifiable limitation on the constitutional right to strike. A further concern with Grogan AJ's three-point test is that the question whether the three requirements have been satisfied is only capable of determination once the matter goes to court. At that stage, the strike may have already existed for months. However, on the other hand it may be useful in that it will force employees to stop striking once the matter eventually goes to court and may also enable the employer to claim compensation from strikers.

Thus, in South Africa only employed and former unionized and nonunionized workers, federations and confederations are allowed to strike. Individual employees are not allowed to strike. This is compatible with ILO standards, which are broad and flexible. The ILO allows states to adopt laws that enable individual workers, unionized and non-unionized workers, and federations and confederations to call strikes, but it also give provides states with the discretion to deny the right to strike to individual employees and non-unionized workers. However, while compatible with ILO standards the LRA may still be unconstitutional. It denies individual workers a right to strike which is guaranteed by section 23(2)(c) of the South African Constitution.

The LRA also gives employees and former employees the right to strike. This goes further than what is required by ILO standards. The meaning and application of these provisions are unclear. It is submitted that an amendment that denies former employees the right to strike should be encouraged since it would remove any pre-existing uncertainties as well as comply with ILO standards. An amendment that provides individual employees with the right to strike is also encouraged since there is no primary reason to deny them this right. Providing them with a right to strike would also serve to comply with South Africa's constitutional obligations and, at the same time, be compatible with ILO standards.

\section{Protest action}

According to section 77(1)(a) of the LRA, protest action may only be called for by a registered union or a federation of trade unions. This is compatible with ILO standards that allow states to restrict strikes to trade unions alone. ${ }^{97}$ However, the constitutionality of section $77(1)$ (a) is questionable since it denies individual employees, non-unionized employees and unregistered

97 Case No 834 (Greece) 160th Report of the CFEA. 
unions the right to strike. Although the right to strike can be limited there is no reason for denying these groups the right to strike. Although one could argue that these restrictions are necessary, since protest action harms innocent employees who are not party to the dispute, the same principle could apply to registered unions. To allow registered unions to participate in protest action would also harm an innocent employer. Allowing only registered unions the right to protest thus violates the right to strike of individual employees, non-unionized employees and unregistered unions. ${ }^{98}$ It also violates their right to equality ${ }^{99}$ since they are being denied a right that unionized employees are given.

\section{CONCLUSION AND SUGGESTIONS}

The definition of strikes in South African law complies with ILO standards. Both recognize that strikes may occur for three different purposes. These include primary strikes for employment conditions against the primary employer, secondary strikes that support primary strikes and protest action against socio-economic policies of the state. Both also recognize that strikes may take various forms provided that they are peaceful. However, the exclusion of overtime bans from the definition of protest action is unnecessary and it is submitted that this be amended. It is also submitted that the term lockout be amended. Unlike complete strikes, other forms of strikes such as partial strikes, grasshopper/intermittent strikes, work-to-rule strikes, go-slows, obstruction of work and overtime bans may have a greater potential to be more disruptive. While primary employers are able to lock these employees out and force them to partake in a complete strike, this option is currently not available to secondary employers and employers subjected to protest action. It is therefore suggested that the definition of lockout be amended to enable these employers to have access to defensive lockouts.

As regards the category of workers who may strike, South African law is in compliance with ILO standards, but unconstitutional. In South Africa only employed and former unionized and non-unionized workers, federations and confederations are allowed to strike and only registered trade unions, confederations and federations are allow to call for protest action. This is compatible with ILO standards, which allow states to adopt laws that enable individual workers, unionized and non-unionized workers and federations and confederations to call strikes, but also give states the discretion to deny the right to strike to individual employees and non-unionized workers. This violates section 23 of the Constitution, which guarantees every employee the right to strike. It is thus submitted that the definition of strike be amended to permit individual employees to strike and that the definition of protest action be amended to provide individual employees, non-unionized employees and unregistered unions with a right to protest. As regards primary and secondary strikes, it is submitted further that the definition be amended to prevent former employees from striking. The law is unclear concerning the

S 23(2)(c) of the 1996 Constitution.

99 Ibid. 
manner in which the categories of former employees who may strike is to be determined. In any event, an employee who has been unfairly dismissed has recourse to adjudication. Thus, while South African law does generally comply with ILO standards, it is important that the above suggested amendments be put into effect so as to provide greater protection to striking employers. This will ensure that strikers are given actual protection so that our constitutional values and fundamental rights are protected. 